\title{
Corneal Donation: Current Guidelines and Future Direction
}

\section{Majid Moshirfar (D) \\ Varshini S Odayar D \\ Shannon E McCabe \\ Yasmyne C Ronquillo}

'Hoopes Vision Research Center, Draper, UT, 84020, USA; ${ }^{2}$ John A. Moran Eye

Center, Department of Ophthalmology and Visual Sciences, University of Utah

School of Medicine, Salt Lake City, UT, 84I32, USA; ${ }^{3}$ Utah Lions Eye Bank,

Murray, UT, 84I07, USA; ${ }^{4}$ Department of Molecular and Cellular Biology, Harvard University, Cambridge, MA, USA;

${ }^{5}$ Mission Hills Eye Center, Pleasant Hill, CA, 94523, USA
Correspondence: Majid Moshirfar Hoopes Vision Research Center, I 1820 State Street, Draper, UT, 84020, USA

$\mathrm{Tel}+$ I 80I-568-0200

Email Cornea2020@me.com
Purpose: This review aims to outline current practices and guidelines of corneal donation and eye banking, describes the implications of COVID-19 and emerging diseases on the corneal donor pool, and discusses future trends to improve and increase the efficiency of the processes involved in corneal donation and eye banking.

Summary: Corneal screening, preservation, corneal storage, and prevention of systemic disease transmission from donor to recipient have been crucial in shaping the policies of the FDA and eye banks across the world. Eye banks globally have developed varying guidelines and criteria for evaluating the viability of donor corneas. Variables such as the age of the donor, medical history, and potential disease transmission are important screening parameters. While known infectious diseases may be transmissible through the cornea, emerging infectious diseases that are not well studied may be more transmissible than other infections. In particular, coronavirus has impacted corneal transplantation as SARS-CoV-2 expression has been detected in corneal tissue and conjunctiva. In recent years, partial-thickness corneal transplantations have been introduced. Lamellar grafts and other corneal layers are now utilized for transplantation of the specific areas that are damaged.

Keywords: donor cornea, eye bank, COVID-19, cornea transplant, keratoplasty, donor recipient

\section{Introduction}

Corneal blindness is one of the leading global causes of blindness, with nearly 12.7 million people requiring a transplant. However, the ratio of corneas available to those required is a mere 1 in $70 .{ }^{1}$ Corneal transplantation has enabled us to replace damaged parts of the cornea, allowing for restoration of sight. For successful corneal transplantation, several factors must be considered, including screening parameters, preservation technique storage, transport, and the evaluation of corneal tissue using serological testing and imaging. Initial clinical screening of the patient's medical history is crucial in determining past or recent potential for infectious disease transmission via corneal transplant. The Eye Bank Association of America (EBAA) plays a vital role in creating the standards for the evaluation of donor tissue, distribution, and quality assurance. Eye banks all over the world play a similar role in evaluating corneal tissue for transplantation.

Previously, surgeons typically transplanted full-thickness corneas in order to restore vision. Corneal transplantation methods are evolving to replace only specific layers of the cornea. It is important to note that COVID-19 has affected corneal transplantation due to the presence of SARS-CoV-2 in conjunctival swabs, which has been confirmed by several different studies. $^{2-4}$ However, evidence of direct 
transmission is yet to be determined. Due to the various potential risks, several eye banks, including the EBAA, have developed specific guidelines to prevent disease transmission via the ocular surface.

\section{Evolution of Corneal Preservation}

For several years, corneal transplantation was a timesensitive process that required obtaining tissue from deceased donors, immersing the tissue in saline, and immediately transferring the tissue to the recipient within hours of harvest. However, the 1930s marked a change whereby collected corneal tissue was stored in moist chambers in ice. ${ }^{5}$ Such methods of preservation for more extended periods are even more prevalent today. The US Food and Drug Administration (FDA) guidelines allow for corneal preservation in solution for a maximum time period of 14 days. $^{6}$ In 2017, Rosenwasser et al conducted the Cornea Preservation Time Study (CPTS), a national clinical trial through which they showed that corneal donor tissue can be stored for up to eleven days to ensure proper transplantation of cornea and restoration of vision. ${ }^{7}$ However, despite such data, surgeons in the United States have largely refrained from using corneas preserved for longer than 7 days. Several scientists have suggested that such practices are rooted in opinion instead of scientific evidence. ${ }^{7}$

Current corneal transplantation techniques utilize various approaches for the preservation and storage of donor cornea. In order for proper corneal transplantation to occur, the corneal endothelium must be viable. Preservation of endothelium is crucial in transplantation because the proliferation of endothelial cells is limited in situ as they are arrested in the G1 phase of the cell cycle. $^{8}$

There are three primary approaches to corneal preservation: organ culture, hypothermia, and cryopreservation. ${ }^{5}$ Organ culture is a method of preservation whereby corneas are incubated in tissue culture medium which can contain additional supplements such as antibiotics or antimycotics. ${ }^{9}$ Hypothermia is another technique whereby donor eyes are stored at low temperatures as it significantly decreases the cell's demand to use metabolic energy. $^{5}$ Cryopreservation requires storage at subfreezing temperatures, typically below $-80^{\circ} \mathrm{C}{ }^{10}$ Cryopreservation, the preservation of tissues by cooling at low temperatures, provides longer storage times compared to organ culture and hypothermia. ${ }^{5}$ However, cryopreservation has been shown to be harmful as freezing corneas leads to endothelial damage via intracellular freezing or solution effect injury. ${ }^{11}$ Several studies have shown that cryopreservation is the most effective method of storing corneal stromal lenticules. ${ }^{12}$ Cryopreservation is crucial for deep anterior lamellar keratoplasty (DALK), a partial-thickness transplantation of corneal stroma. Mohamed-Noriega et al examined the collagen structure of stromal lenticules retrieved from refractive lenticule extraction (ReLEx) following a one-month period of cryopreservation. They concluded that the architecture of the collagen and viability of keratocytes was retained after cryopreservation. ${ }^{13}$ In contrast, hypothermic storage at 2$8{ }^{\circ} \mathrm{C}$ is widely used and accepted as the more effective means of preservation. ${ }^{5}$ However, standard methodology for lenticule harvest and preservation is yet to be established as methods are continuously evolving.

In the US, eye banks primarily utilize Optisol-GS as the storage solution, which consists of dextran, chondroitin sulphate, and vitamins. ${ }^{5}$ The McCarey-Kaufman medium (M-K medium) consisting of culture medium 199 and dextran 40 is also utilized in many countries but has a limited storage time of 2-4 days. ${ }^{11}$ In 2005, Wagoner et al determined the mean Optisol-GS storage time to be $237.1 \pm 41.6$ hours (7-14 days). ${ }^{14}$ The Optisol-GS solution alone lacks antifungal supplements. Several cases of corneal transplantation have reported candida keratomycosis. $^{15}$ Antifungal additives to Optisol-GS, such as amphotericin, have been proven to limit the growth of fungal colonies, particularly those of the Candida species, one of the most frequent causes of postcorneal transplant fungal infections. ${ }^{16}$

For stromal lenticules, cryopreservation in glycerol solution has proved to be cheaper and more effective. ${ }^{12}$ Glycerol has antimicrobial characteristics due to its role as a dehydrating agent and is thereby more potent in longterm preservation. ${ }^{17}$ Other commonly utilized solutions for cryostorage include Dulbecco's Modified Eagle's Medium (DMEM), serum-free medium (SFM), and Dexsol. ${ }^{12}$ Greenbaum et al show that corneal epithelium can be stored effectively in both Optisol-GS and Dexsol with no significant differences in viability and preservation of epithelium among both solutions. ${ }^{18}$ However, it is important to recognize that a thorough comparison of preservation methods for corneal epithelium is yet to be reported.

Organ culture is a third preservation approach most commonly used in European eye banks where eyes are rinsed with saline, placed in povidone-iodine solution, and later suspended in Eagle's minimum essential medium 
(MEM). Through this medium, corneas can be preserved for a maximum period of 4 weeks. ${ }^{5}$ In comparison to hypothermia, organ culture allows for the identification of bacteria and fungi, which could cause infection following transplantation. ${ }^{5}$ Organ culture medium can be utilized for storing Bowman Layer (BL) grafts. Located between the epithelial basement membrane and the anterior corneal stroma, BL is primarily comprised of collagen fibers, providing structural support. BL transplantation, a minimally invasive method where $\mathrm{BL}$ is inserted into a stromal pocket, is used to treat keratoconus. ${ }^{19}$ Similarly, Descemet's membrane, the basement membrane of the corneal endothelium, is often isolated for use in Descemet Membrane Endothelial Keratoplasty (DMEK), a partial-thickness transplant used to treat damaged corneal endothelium. DMEK grafts can also be stored in organ culture medium or growth factor-containing enhanced medium (En-OC). ${ }^{20}$ Romano et al compared various forms of preservation in DMEK procedures by testing endothelial viability among endothelium placed in organ culture versus hypothermic conditions. They concluded that endothelium stored in organ culture was viable for 30 days compared to 14 days in hypothermic storage. ${ }^{21}$

\section{Corneal Evaluation and Eye Bank Guidelines}

Prior to transplantation, eye banks perform a thorough screening of the eye donors for eligibility. The EBAA provides detailed guidelines and medical standards for corneal transplantation (Table 1). The EBAA requires that each donor is identified by name. Their medical standards call for a consistent method of examination and documentation of donor eligibility within each eye bank. ${ }^{22}$ The guidelines in Table 2 summarize the necessary information and procedures required for effective donor eligibility determination, but is not limited to those listed in the table. Generally, eye banks in the US perform three primary tests, including serological testing, review of donor's medical history, and physical inspection of corneas using imaging technique. Serological testing is performed using donor blood collected during tissue procurement. $^{23}$ It is important to note that corneal transplantation does not require that donors and recipients have the same blood type because the cornea is an immuneprivileged environment and does not contain blood vessels. ${ }^{24}$ The risk of transplant failure due to $\mathrm{ABO}$ incompatibility is not increased. ${ }^{25}$ The donor is screened
Table I Eye Bank Association of America Donor Screening Guidelines $^{22}$

\begin{tabular}{|l|l|}
\hline \multirow{7}{*}{ EBAA Testing } & Requirements \\
& $\begin{array}{l}\text { The following tests must be completed and must } \\
\text { return a negative or non-reactive test result. A } \\
\text { (I). Anti-HIV-I, Anti-HIV-2 } \\
\text { (2). Hepatitis B Surface Antigen (HBsAg) } \\
\text { (3). Anti-HCV }\end{array}$ \\
\hline FDA Testing & $\begin{array}{l}\text { The FDA recommends the following tests: } \\
\text { (I). HIV, Type I: FDA licensed screening test for } \\
\text { anti-HIV-I or combination for test for anti-HIV-I and } \\
\text { anti-HIV-2, FDA licensed Nucleic Acid (NAT) test } \\
\text { for HIV-I or combination NAT } \\
\text { (2). HIV, Type 2: anti-HIV-2 test or combination test } \\
\text { (3). HBV: FDA licensed test for HBsAg, total } \\
\text { antibody to Hepatitis B core antigen (anti-HBc), and } \\
\text { NAT screening for HBV } \\
\text { (4). HCV: Screening Test for HBsAg, total antibody } \\
\text { to Hepatitis B core antigen (anti-HBc), and NAT } \\
\text { donor test } \\
\text { (5). Treponema pallidum: screening test for syphilis }\end{array}$ \\
\hline State & $\begin{array}{l}\text { Other requirements and guidelines may vary in } \\
\text { accordance with state. }\end{array}$ \\
\hline Requirement \\
$\begin{array}{l}\text { According to country of import of donor tissue, } \\
\text { various testing requirements may arise. }\end{array}$
\end{tabular}

Note: Data from Eye Bank Association of America (EBAA). ${ }^{22}$

for hepatitis B, hepatitis C, syphilis, and HIV, among other infectious diseases. ${ }^{23}$ After preliminary screenings, the cornea is examined utilizing various imaging techniques to assess the general quality of corneal tissue. ${ }^{23}$

\section{Eye Banks and Eye Bank Associations}

Eye banks play a crucial role in the evaluation and distribution of ocular tissue for transplantation. There are different types of eye banks in the United States, such as non-profit, for-profit corporations, consortium, and university-based eye banks. For instance, Lions Eye Bank consists of more than 60 eye banks worldwide, all operated by a non-profit foundation. ${ }^{26}$ In contrast, CorneaGen serves as a for-profit business entity with the goal of eliminating corneal blindness. ${ }^{26}$ The Eye Bank Association of America (EBAA) represents 83 eye banks across the United States as well as 14 international eye banks. ${ }^{27}$ Within the United States, eye banks must be credentialed by the EBAA as well as the FDA. ${ }^{22}$ The credentialing process occurs every 3 years, whereby an 
Table 2 Eye Bank Association of America Donor and Donor Eye Eligibility Guidelines ${ }^{22}$

\begin{tabular}{|c|c|}
\hline $\begin{array}{l}\text { Infectious Disease } \\
\text { Testing }\end{array}$ & See Table I for the Following Conditions \\
\hline $\begin{array}{l}\text { Physical Assessment of } \\
\text { Donor }\end{array}$ & $\begin{array}{l}\text { The donor must be examined for signs of: } \\
\text { (1). HIV } \\
\text { (2). Infectious Hepatitis } \\
\text { (3). Intravenous Drug Use }\end{array}$ \\
\hline Tissue Evaluation & $\begin{array}{l}\text { Corneal tissue must be evaluated through an array of methods including slit lamp examination, endothelial cell density, } \\
\text { and pachymetry measurement. }\end{array}$ \\
\hline Donor History Evaluation & 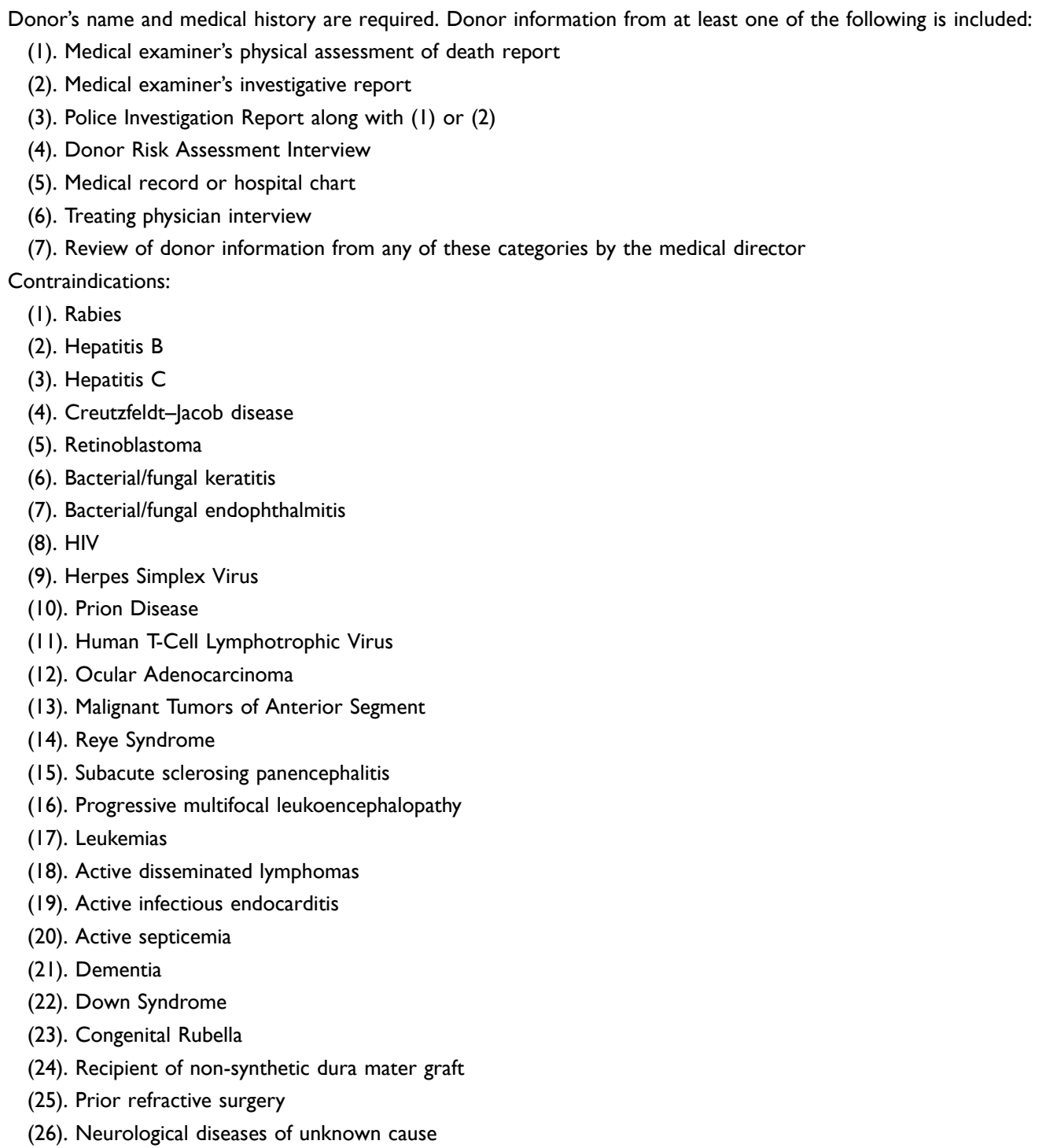 \\
\hline $\begin{array}{l}\text { Important } \\
\text { Considerations }\end{array}$ & $\begin{array}{l}\text { (1). Donors are deemed ineligible if they have received a tattoo within the past } 12 \text { months using unsterile } \\
\text { instruments. } \\
\text { (2). Transgender populations are largely omitted in EBAA guidelines. }\end{array}$ \\
\hline
\end{tabular}

Note: Data from Eye Bank Association of America (EBAA). ${ }^{22}$ 
eye banker and corneal surgeon perform site inspections to assess compliance to the medical standards of the EBAA, standards which have been endorsed by the American Academy of Ophthalmology. ${ }^{28}$ The process consists of two stages, including pre-inspection as well as on-site inspection. The eye bank completes a preinspection questionnaire (PIQ) reporting on staff qualifications as well as testing processes and maintenance. During the on-site inspection, operating procedures, donor records, equipment, and administrative documentation are reviewed in detail. The team concludes by completing a site inspection questionnaire (SIQ) to document their observations, and further outlines any necessary corrective actions and preventive actions (CAPA). EBAA Accreditation Board later convenes to grant an eye bank with one of three forms of accreditation: 3 years, 1 year, or denial of accreditation. ${ }^{28}$

It is also important to note the coroner's role in eye banking. The coroner is crucial in authorizing the preautopsy release of corneal tissue; thus, the coroner's office and eye bank should maintain good communication. ${ }^{29}$ For instance, the Rocky Mountain Lions Eye Bank recommends that coroners sign a protocol with each eye bank to ensure that specific standards are met. ${ }^{29}$ This is significant as time impacts the preservation of corneal tissues. ${ }^{29}$

\section{Corneal Tissue Imaging Analysis for Different Types of Transplants}

After screening for eligibility, slit-lamp biomicroscopy and ancillary imaging are crucial tools in the complete evaluation of the cornea. ${ }^{30}$ Specifically, slit-lamp biomicroscopy is utilized to detect endothelial disease and further examine the epithelium and stroma. The presence of corneal edema, scarring, stress lines, arcus, pterygia, neovascularization, striae, central guttata, polymegathism, pleomorphism, and infiltrates may all indicate issues of viability. ${ }^{22}$ The EBAA also asks that eye banks define and mark a "clear zone" on the cornea, measuring the diameter of the cornea that is absent of conditions such as scarring, stress lines, and other pathologies. ${ }^{22}$ Specular microscopy is another imaging technique essential for examining endothelial cell morphology and viability. ${ }^{30}$ Pachymetry is a third technique wherein a probe is used to measure the thickness of the cornea. ${ }^{31}$ Corneal thickness is important as it may indicate corneal swelling as seen in conditions such as Fuchs' dystrophy. ${ }^{32}$ Transplantation methods involving specific corneal layers require varying criteria for evaluation (Table 3).

While evaluation criteria for whole donor corneas remain the same across these different procedures, many additional criteria are unique to the corneal layer transplanted. During Bowman's Layer Transplantation (BLT), the graft is harvested via separation of the BL from the anterior stroma layer taken from either corneoscleral rims or entire donor globes. ${ }^{33}$ Sharma et al have shown that both methods result in very similar success rates, reporting rates of $69.4 \%$ and $72.2 \%$ for globes and corneoscleral rims, respectively. ${ }^{33}$ The primary evaluation criteria for BL grafts include tearing of the BL and thickness of graft. ${ }^{34} \mathrm{~A}$ thick BL graft may contain additional stromal tissue, leading to poor quality of vision following transplantation. Tearing of the BL leads to damage of tissue, thus rendering it non-viable. Damage to Bowman's Layer can also indicate damage to the stroma as the $\mathrm{BL}$ is formed early in development and cannot be repaired later. $^{34}$

DMEK transplantations present another set of criteria due to the intricacy of the procedure. Donor tissue selection is thus crucial for the DMEK process. Specifically, the DMEK procedure recommends that tissues be harvested from donors of age 55 and older because tissue from those who are younger tends to create compressed scrolls, thus posing intraoperative challenges as the scroll must later unfold in the procedure. ${ }^{35}$ However, this topic is a source of debate as other scholars, specifically Schaub et al, found that younger donor age did not, in fact, alter the outcome of DMEK within the first postoperative years. ${ }^{36}$ Schaub et al reviewed 1084 consecutive DMEKs and found that corneal donors with minimum age of 17 years were viable donors. ${ }^{36}$ The endothelial cell density can be examined through specular microscopy and successful transplantation often requires cell densities greater than 2500 cells/ $\mathrm{mm}^{2} .37$

While slit-lamp imaging provides a broad inspection of the tissue, specular microscopy is essential for identifying corneas with marginal functional reserve and evaluating endothelial cell density. ${ }^{38}$ Corneal endothelium contains a large number of hexagonal cells of specific size, and thus significant variation in cell size (polymegathism) further indicates non-viable tissue. ${ }^{38}$ Various eye banks require a minimum endothelial cell density for corneal endothelium transplantation. ${ }^{39}$ In a recent study published in 2018, Batista et al have shown that high-resolution twophoton imaging is another technique capable of examining 
Table 3 Criteria for Evaluation of Corneal Tissue for Transplantation Procedures ${ }^{22}$

\begin{tabular}{|c|c|}
\hline & Contraindications \\
\hline Penetrating Keratoplasty (PK) & $\begin{array}{l}\text { Infiltrates, pterygia, } \\
\text { neovascularization, foreign bodies, } \\
\text { stromal scars in graft area, } \\
\text { detachment of Descemet's } \\
\text { membrane, endothelial dystrophy, } \\
\text { low endothelial cell density, Down } \\
\text { syndrome, ectatic dystrophy } \\
\text { (keratoconus, keratoglobus), } \\
\text { previous refractive surgery (laser } \\
\text { and incisional) }\end{array}$ \\
\hline $\begin{array}{l}\text { Anterior Lamellar Keratoplasty } \\
\text { (ALK/DALK) }\end{array}$ & $\begin{array}{l}\text { Infiltrates, pterygia, } \\
\text { neovascularization, foreign bodies, } \\
\text { stromal scars in graft area, Down } \\
\text { syndrome, ectatic dystrophy, } \\
\text { previous refractive surgery }\end{array}$ \\
\hline $\begin{array}{l}\text { Descemet's stripping } \\
\text { endothelial keratoplasty } \\
\text { (DSEK/DSAEK) }\end{array}$ & $\begin{array}{l}\text { Infiltrates, scars impacting } \\
\text { posterior stroma in graft area, } \\
\text { detachment of Descemet's } \\
\text { membrane, low endothelial cell } \\
\text { density, low rim size and } \\
\text { corneoscleral disc size (necessary } \\
\text { for mounting on anterior chamber) }\end{array}$ \\
\hline $\begin{array}{l}\text { Descemet's membrane } \\
\text { endothelial keratoplasty } \\
\text { (DMEK) }\end{array}$ & $\begin{array}{l}\text { Infiltrates, foreign bodies, tears in } \\
\text { Descemet's membrane in graft } \\
\text { area, low endothelial cell density }\end{array}$ \\
\hline Keratolimbal Allograft (KLA) & $\begin{array}{l}\text { Infiltrates, small scleral rim, } \\
\text { conjunctiva not intact over the rim, } \\
\text { melanoma, cancer of solid organ }\end{array}$ \\
\hline Keratoprosthesis (K-Pro) & $\begin{array}{l}\text { Infiltrates, pterygia, } \\
\text { neovascularization, foreign bodies, } \\
\text { significant thinning of the cornea, } \\
\text { prior refractive surgery, Down } \\
\text { syndrome, ectatic dystrophy }\end{array}$ \\
\hline
\end{tabular}

Note: Data from Eye Bank Association of America (EBAA). ${ }^{22}$

the metabolic state of endothelial cells and the structure of the stroma. ${ }^{40}$ In addition, stromal opacity, transparency, and scarring are all critical parameters for determining the viability of transplantation of stromal tissues. ${ }^{41}$

Such parameters can be evaluated using full-field optical coherence microscopy (FFOCM), confocal microscopy (CM), and histology. Over the past few years, many new methods and imaging techniques have been studied to determine their efficacy and future promise for evaluating donor cornea. Imaging techniques such as high-resolution confocal microscopy may become more prevalent and evolve to a standard procedure in corneal evaluation. Optical coherence tomography (OCT), and more specifically, anterior segment-OCT (AS-OCT), is a noninvasive method that is particularly useful in evaluating epithelial thickness and conjunctivalized corneas. ${ }^{42}$

The impact of femtosecond lasers in corneal transplantation procedures should be considered. Femtosecond lasers can be utilized for several anterior refractive procedures such as penetrating keratoplasty, laser in situ keratomileusis (LASIK), DALK, and DSEK. The laser allows for bladeless incisions with very high precision. ${ }^{43}$ Furthermore, femtosecond lasers allow a single donor tissue to be utilized for several recipients undergoing various forms of corneal transplantation. The femtosecond laser is reported to provide better wound stability along with decreased recovery times. ${ }^{44}$

\section{Current Criteria for Corneal Donation in the United States}

Eye banks in the US typically require that donors be younger than 65 years of age. ${ }^{45}$ However, several debates surrounding the topic have emerged as scholars disagree on whether donor age is a proper indicator of the quality of donor cornea. For instance, Mannis et al determined that the ten-year success rate of corneal transplantation, specifically penetrating keratoplasty, was determined to be $75 \%$ for transplants from donors aged 34-71 years old. ${ }^{46}$ It is reported that nearly $75 \%$ of donors in the US fall within this age range and one-third of the donors fall within the age range of 61-70. The study utilized 1090 corneas from donors aged 12-75. Furthermore, they found that the success rate was higher for donors aged $12-33$ years $(96 \%$ for 80 donors) in comparison to donors aged $72-75$ (62\% for 120 donors). However, the study concluded that age is not a crucial factor in the success of transplantation for penetrating keratoplasty due to the similar success rate for donors aged 34-71. ${ }^{46}$ Thus, data indicate that cornea donors older than 65 years can result in successful transplantation. As surgeons typically refrain from utilizing corneal tissue from older donors to maximize success rates, it is expected that the pool of younger donors will decrease significantly in comparison to donors 65 years and older.

On May 20, 1994, the FDA has also instituted guidelines, which has led to a decrease in the pool of donor corneas. ${ }^{47}$ The FDA established a policy whereby men who have had sex with men (MSM) in the past 5 years 
are prohibited from serving as corneal donors. While introduced several decades ago, the policy remains in place and is enforced by the FDA. In the 2018 calendar year alone, the policy led to a removal of approximately 1600 potential donors from the donor pool. During the introduction of the policy, HIV tests were deemed unreliable for up to 6 months following exposure. ${ }^{47}$ However, Puente et al discuss that modern virology techniques can effectively detect HIV after a few days of exposure. Thus, they call for reformulation of such policies as they prevent thousands of donor corneas from being utilized. ${ }^{47}$

The FDA and EBAA have not established guidelines surrounding the ability of transgender individuals to donate corneal tissue. FDA policies typically call for gender self-identification. ${ }^{48}$ However, for instance, regarding the MSM policy, no clear guidelines exist for transgender individuals who may not identify as a specific gender. ${ }^{49}$ Consequently, this expresses the need to revise policies and include transgender populations. ${ }^{49}$

\section{Risks for Disease Transmission}

The potential for transmission of infection through corneal transplantation has been documented by various studies. Current documented cases of transmission include hepatitis B, Creutzfeldt-Jakob disease (CJD), and rabies. ${ }^{50} \mathrm{CJD}$ is a fatal neurodegenerative disorder caused by an abnormal form of prion. ${ }^{51}$ Contraindications to transplantation include herpes simplex virus, hepatitis B, syphilis, tuberculosis, smallpox, and malaria, among many others. ${ }^{52}$ Keratoplasty was the first procedure that proved transmission of virus through corneal transplantation. ${ }^{53}$ Remeijer et al were the first to show that HSV-1 (herpes simplex virus) can be transmitted through penetrating keratoplasty. ${ }^{54}$ Several years later, EBAA medical advisory board reported 31 cases of postoperative fungal keratitis $(n=14)$ and endophthalmitis $(n=17)$ out of 221,664 corneal transplants. ${ }^{55}$ Currently, the SARS-CoV-2 strain presents a significant threat to corneal transplants.

The EBAA has also determined that many viruses can be transmitted during corneal transplantation, including the West Nile, Ebola, Zika, and Vaccinia viruses. ${ }^{56}$ However, according to the EBAA, there is a lack of sufficient evidence to confirm the transmission of such viruses through corneal transplants. ${ }^{22}$

Individuals with tattoos have been a topic of contention regarding the ability to serve as a corneal donor. Tattoos may significantly increase the likelihood of the donor transmitting viruses such as hepatitis B and C, HIV, and molluscum contagiosum. ${ }^{57}$ The EBAA guidelines recommend that individuals who have received a tattoo or any body piercings in the past 12 months without the use of sterile procedures or sterile instruments (ie, use of shared instruments unsterilized between use) be considered ineligible for corneal donation. ${ }^{22}$

\section{SARS-CoV-2 and Emerging Eye Bank Guidelines}

COVID-19 manifestations include conjunctivitis. ${ }^{58}$ Studies have detected the presence of COVID-19 in conjunctival swabs. ${ }^{2-4,59-61}$ A case report indicated the presence of SARS-CoV-2 RNA in tears for up to 27 days after initial onset. ${ }^{61}$ However, the evidence does not prove whether SARS-CoV-2 can be directly transmitted through an ocular surface. ${ }^{62}$

SARS-CoV-2 infects the cell through the ACE2 receptor upon priming of cellular protease using transmembrane serine protease 2 (TMPRSS2). ${ }^{62}$ A recent study published in 2021 investigated the expression of SARS-CoV-2 entry genes in corneal and conjunctival epithelium. Collin et al utilized single RNA Seq and ATAC-Seq datasets to discover co-expression of ACE2 and TMPRSS2. ${ }^{62}$ They also found that inflammatory signals upregulated the expression of ACE2+TMPRSS2+ cells, showing that the ocular surface epithelium is a site of SARS-CoV-2 entry. ${ }^{62}$ Sawant et al examined expression of SARS-CoV-2 in corneal tissue using RT-PCR. ${ }^{63}$ The study used tissues from 33 surgical-intended donors removed from the donor pool due to EBAA or positive COVID test results. ${ }^{63}$ They detected a positivity rate of $13 \%$ (17 of 132 ocular tissues), indicating a notable prevalence of SARS-CoV-2 in ocular tissue and emphasizing the importance of donor screening guidelines. ${ }^{63}$

Studies have also indicated that the virus infects the upper respiratory tract, and consequently coughing or sneezing may lead to contamination of the ocular surface. ${ }^{58}$ While such data points to the presence of virus in the corneal epithelium and ocular surface, there is no direct evidence proving transmission of the virus through corneal transplantation. Regardless, due to uncertainty regarding potential dangers of transmission, the EBAA and the Global Alliance of Eye Bank Associations (GAEBA) have advised that donors who are PCR positive for SARS-CoV-2 be removed from the donor pool. ${ }^{56}$ The EBAA thereby excludes various groups of individuals 
Table 4 Eye Bank Association of America (EBAA) Guidelines for Evaluation of Viable Donors ${ }^{68}$

\begin{tabular}{|c|c|}
\hline Criteria & $\begin{array}{l}\text { Recommendations for Corneal Viability of Donors } \\
\text { with Potential COVID-19 Infection }\end{array}$ \\
\hline PCR Test & $\begin{array}{l}\text { RT-PCR test must be performed either } 24 \text { hours after } \\
\text { death or within } 28 \text { days prior to death. Donors should } \\
\text { be excluded if the test is inconclusive. }\end{array}$ \\
\hline Signs & $\begin{array}{l}\text { If donor contracted any of the following signs within } 28 \\
\text { days prior to death, donor cornea is not viable. The } \\
\text { signs include: } \\
\text { (1) Acute respiratory distress syndrome (ARDS) } \\
\text { (2) Pneumonia } \\
\text { (3) Detection of "ground glass opacities" via pulmonary } \\
\text { computed tomography (PCT) }\end{array}$ \\
\hline Symptoms & $\begin{array}{l}\text { If donor had various symptoms consistent with criteria } \\
\text { below within } 28 \text { days prior to death, donor cornea is } \\
\text { not viable. } \\
\text { One from the below: } \\
\text { (1) Fever or chills } \\
\text { (2) Difficulty breathing or shortness of breath } \\
\text { (3) Coughing } \\
\text { (4) Loss of taste or smell } \\
\text { OR two from the below: } \\
\text { (1) Headache } \\
\text { (2) Sore Throat } \\
\text { (3) Congestion } \\
\text { (4) Nausea } \\
\text { (5) Fatigue } \\
\text { (6) Muscle Aches }\end{array}$ \\
\hline Contact & $\begin{array}{l}\text { Donor being within six feet of a COVID-19 case or in } \\
\text { direct contact with secretions from COVID-case }\end{array}$ \\
\hline Vaccination & $\begin{array}{l}\text { At the time of death, donor would be considered as } \\
\text { fully vaccinated under two conditions: } \\
\text { (1) } 2 \text { weeks have passed since donor's second dose in } \\
\text { a } 2 \text {-dose series such as the Pfizer or Moderna vaccines. } \\
\text { (2) } 2 \text { weeks have passed after a single-dose vaccine } \\
\text { such as Johnson \& Johnson's Janssen vaccine }\end{array}$ \\
\hline
\end{tabular}

Note: Data from Eye Bank Association of America (EBAA) (URL: https://restore sight.org/covid-19-updates/). ${ }^{68}$

from the donor pool (Table 4). Several eye bank associations in various countries, such as the European Eye Bank Association (EEBA), have developed their own guidelines. The EEBA primarily requires a PCR test. If the PCR test is positive 14 days prior to death, the donor is ineligible. ${ }^{64} \mathrm{In}$ addition, a nasopharyngeal swab postmortem is typically performed. ${ }^{64}$ However, individual risk assessment is necessary to determine the eligibility of the donor. It is important to note that postmortem swabs are yet to be validated. $^{64}$
Several studies have also examined the potential to reduce the expression of SARS-CoV-2 in corneal tissue. Sawant et al investigated the potential of povidone-iodine in the inactivation of SARS-CoV-2. ${ }^{63}$ The team isolated the right eyes as the control group and the left eyes as the variable, utilizing a double-soak procedure with povidone-iodine. The team found that all left eyes produced negative results, whereby one of the right eyes produced a positive result. However, due to a small sample size of only 10 patients, the data could not determine a proper correlation. ${ }^{63}$ Thus, this study has many implications for future studies as povidone-iodine could prove to be a potential inactivator of COVID-19 if tested with a larger sample size. While povidone-iodine may be promising in reducing SARS-CoV-2 expression, other barriers pose significant challenges. Due to screening conditions and regulations within eye banks such as the EBAA, the donor eligibility review process is often delayed, leading to longer preservation times. $^{65}$

\section{Future Guideline Changes}

Currently, the primary purpose of eye banks is storage, evaluation, and distribution of corneal tissues for transplantation. However, there has been a recent emerging focus on the storage of stromal lenticules. Corneal lenticules may be utilized for new indications such as presbyopia, corneal allogenic intrastromal ring segment implantation (CAIRS), hyperopic SMILE, myopic SMILE, tissue augmentation, and mechanical reinforcement for ectatic disorders.

In the aftermath of COVID-19, several changes in eye banking may be necessary. Ang et al reported that collaboration between eye bank technicians and surgeons must be prioritized. ${ }^{66}$ Furthermore, proper training methods are necessary for surgeons and technicians alike. Patient education is also crucial as information regarding risks of transmission must be conveyed clearly and effectively. Ang et al expressed the need to routinely evaluate donor viability criteria as the supply chain must continue. ${ }^{66}$

Most importantly, the donor pool can be expanded through significant improvement of corneal evaluation methods and techniques. Furthermore, increasing the storage time of both full-thickness and corneal layers is an important next step in advancing corneal transplantation efficiency. Corneal tissue culture is cited as a promising approach to optimizing the function of corneal tissue such as the endothelium. ${ }^{67}$ Thus, eye banks may integrate corneal tissue culture into their infrastructure to optimize their operation. The pandemic has further given rise to the need for a new infrastructure upon which corneal transplantation can continue to restore vision. 


\section{Data Sharing Statement}

Not applicable.

\section{Code Availability}

Not Applicable

\section{Author Contributions}

All named authors meet the International Committee of Medical Journal Editors criteria for authorship for this manuscript, take responsibility for the integrity of the work, and have given final approval to the version to be published. All authors contributed to drafting or revising the article, analyzing the literature, gave final approval of the version to be published, agreed to the selected journal and agree to be accountable for all aspects of the work.

\section{Funding}

This study was funded by an unrestricted grant from Research to Prevent Blindness (RPB), 360 Lexington Avenue, 22nd Floor New York, NY 10017. No support was received for the publication of this article.

\section{Disclosure}

No authors have a conflict of interest related to this work.

\section{References}

1. Gain P, Jullienne R, He Z, et al. Global survey of corneal transplantation and eye banking. JAMA Ophthalmol. 2016;134(2):167-173. doi:10.1001/jamaophthalmol.2015.4776

2. Savastano MC, Gambini G, Savastano A. et al. Evidence-based of conjunctival COVID-19 positivity: an Italian experience: gemelli Against COVID Group. Eur J Ophthalmol;2020. 112067212097654. doi:10.1177/1120672120976548

3. Azzolini C, Donati S, Premi E, et al. SARS-CoV-2 on ocular surfaces in a cohort of patients with COVID-19 from the Lombardy Region, Italy. JAMA Ophthalmol. 2021. doi:10.1001/jamaophthalmol. 2020.5464

4. Zhou Y, Duan C, Zeng YM, et al. Ocular findings and proportion with conjunctival SARS-COV-2 in COVID-19 patients. Ophthalmology. 2020;127:982-983. doi:10.1016/j.ophtha.2020. 04.028

5. Armitage WJ. Preservation of human cornea. Transfusion Med Hemother. 2011;38:143-147. doi:10.1159/000326632

6. Lass JH, Szczotka-Flynn LB, Ayala AR, et al. Cornea preservation time study: methods and potential impact on the cornea donor pool in the United States. Cornea. 2015;34(6):601-608. doi:10.1097/ ICO.0000000000000417

7. Rosenwasser GO, Szczotka-Flynn LB, Ayala AR. et al. Effect of cornea preservation time on success of descemet stripping automated endothelial keratoplasty a randomized clinical trial. JAMA Ophthalmol;2017. 1401-1409. doi:10.1001/jamaophthalmol.2017.4989

8. Joyce NC. Proliferative capacity of corneal endothelial cells. Exp Eye Res. 2012;95(1):16-23. doi:10.1016/j.exer.2011.08.014
9. Pels L. Organ culture: the method of choice for preservation of human donor corneas. $B r \quad J$ Ophthalmol. 1997;81:523-525. doi:10.1136/bjo.81.7.523

10. Baust JG, Gao D, Baust JM. Cryopreservation: an emerging paradigm change. Organogenesis. 2009;5:90-96. doi:10.4161/org.5.3.10021

11. Armitage J. Cryopreservation for Corneal Storage. In: Eye Banking. Basel: KARGER; 2009:63-69.

12. Liu YC, Williams GP, George BL, et al. Corneal lenticule storage before reimplantation. Mol Vis. 2017;23:753-764.

13. Mohamed-Noriega K, Toh KP, Poh R, et al. Cornea lenticule viability and structural integrity after refractive lenticule extraction (ReLEx) and cryopreservation. Mol Vis. 2011;17:3437-3449.

14. Wagoner MD, Gonnah ES. Corneal graft survival after prolonged storage in Optisol-GS. Cornea. 2005;24(8):976-979. doi:10.1097/01. ico.0000159731.52801.b6

15. Sun RL, Jones DB, Wilhelmus KR. Clinical characteristics and outcome of Candida keratitis. Am J Ophthalmol. 2007;143(6):1043. doi:10.1016/j.ajo.2007.02.016

16. Layer N, Cevallos V, Maxwell AJ, Hoover C, Keenan JD, Jeng BH. Efficacy and safety of antifungal additives in Optisol-GS corneal storage medium. JAMA Ophthalmol. 2014;132(7):832-837. doi:10.1001/jamaophthalmol.2014.397

17. Li J, Shi S, Zhang X, et al. Comparison of different methods of glycerol preservation for deep anterior lamellar keratoplasty eligible corneas. Investig Ophthalmol Vis Sci. 2012;53(9):5675-5685. doi:10.1167/iovs.12-9936

18. Greenbaum A, Hasany SM, Rootman D. Optisol vs Dexsol as storage media for preservation of human corneal epithelium. Eye. 2004;18 (5):519-524. doi:10.1038/sj.eye.6700693

19. Dragnea DC, Birbal RS, Ham L, et al. Bowman layer transplantation in the treatment of keratoconus. Eye Vis. 2018;5(1):24. doi:10.1186/ s40662-018-0117-y

20. Bhogal M, Matter K, Balda MS, Allan BD. Organ culture storage of pre-prepared corneal donor material for Descemet's membrane endothelial keratoplasty. $B r \quad J \quad$ Ophthalmol. 2016;100 (11):1576-1583. doi:10.1136/bjophthalmol-2016-308855

21. Romano V, Parekh M, Ruzza A, et al. Comparison of preservation and transportation protocols for preloaded Descemet membrane endothelial keratoplasty. $B r J$ Ophthalmol. 2018;102(4):549-555. doi:10.1136/bjophthalmol-2017-310906

22. Eye Bank Association of America-Medical Standards; 2020. Available from: https://restoresight.org/wp-content/uploads/2020/07/ Med-Standards-June-20-2020 7 23.pdf. Accessed May 4, 2021.

23. Lambert N, Chamberlain W. The structure and evolution of eye banking: a review on eye banks\&rsquo; historical, present, and future contribution to corneal transplantation. J Biorepository Sci Appl Med. 2017;5:23-40. doi:10.2147/BSAM.S114197

24. Hori J, Yamaguchi T, Keino H, Hamrah P, Maruyama K. Immune privilege in corneal transplantation. Prog Retin Eye Res. 2019;72:100758.

25. Dunn SP, Stark WJ, Stulting RD, et al. The effect of ABO blood incompatibility on corneal transplant failure in conditions with low-risk of graft rejection. Am J Ophthalmol. 2009;147(3):432. doi:10.1016/j.ajo.2008.09.021

26. Moshirfar M, Goldberg JL, Brown TW, Wagner WD, Ronquillo YC. A paradigm shift in eye banking: how new models are challenging the status quo. Clin Ophthalmol. 2019;13:63-67. doi:10.2147/OPTH. $\mathrm{S} 181534$

27. About the Eye Bank Association of America - Eye Bank Association of America. Available from: https://restoresight.org/eye-bankassociation-america/. Accessed June 10, 2021.

28. Accreditation - Eye Bank Association of America. Available from: https://restoresight.org/accreditation/. Accessed June 10, 2021.

29. Rocky Mountain Lions Eye Bank, Coroner Education Module. Available from: https://corneas.org/coroner-education-work-withcoroners. Accessed June 10, 2021. 
30. Martin R. Cornea and anterior eye assessment with slit lamp biomicroscopy, specular microscopy, confocal microscopy, and ultrasound biomicroscopy. Indian J Ophthalmol. 2018;66:195-201. doi:10.4103/ ijo.IJO_649_17

31. Hashmani N, Hashmani S, Murad A, Asghar N, Islam M. Effect of demographic variables on the regional corneal pachymetry. AsiaPacific J Ophthalmol. 2019;8(4):324-329. doi:10.1097/ APO.0000000000000252

32. Repp DJ, Hodge DO, Baratz KH, McLaren JW, Patel SV. Fuchs' endothelial corneal dystrophy: subjective grading versus objective grading based on the central-to-peripheral thickness ratio. Ophthalmology. 2013;120(4):687-694. doi:10.1016/j. ophtha.2012.09.022

33. Sharma B, Dubey A, Prakash G, Vajpayee RB. Bowman's layer transplantation: evidence to date. Clin Ophthalmol. 2018;12:433-437. doi:10.2147/OPTH.S141127

34. Parker JS, Dockery PW, Melles GRJ. Bowman layer transplantation -a review. Asia-Pacific J Ophthalmol. 2020;9(6):565-570. doi:10.1097/APO.0000000000000336

35. Maharana P K, Sahay P, Singhal D, Sharma N,S, Titiyal J. Donor preparation in descemet membrane endothelial keratoplasty. New Front Ophthalmol. 2019;5:1. doi:10.15761/NFO.1000227

36. Schaub F, Enders P, Zachewicz J, et al. Impact of donor age on Descemet Membrane Endothelial Keratoplasty outcome: evaluation of donors aged 17-55 years. Am J Ophthalmol. 2016;170:119-127. doi:10.1016/j.ajo.2016.08.005

37. Armitage WJ, Dick AD, Bourne WM. Predicting endothelial cell loss and long-term corneal graft survival. Investig Ophthalmol Vis Sci. 2003;44(8):3326-3331. doi:10.1167/iovs.02-1255

38. Specular Microscopy - an overview | scienceDirect Topics. Available from: https://www.sciencedirect.com/topics/medicine-and-dentistry /specular-microscopy. Accessed March 18, 2021.

39. Lass JH, Sugar A, Benetz BA, et al. Endothelial cell density to predict endothelial graft failure after penetrating keratoplasty. Arch Ophthalmol. 2010;128(1):63-69. doi:10.1001/ archophthalmol.2010.128.63

40. Batista A, Breunig HG, König A, et al. Assessment of human corneas prior to transplantation using high-resolution two-photon imaging. Investig Ophthalmol Vis Sci. 2018;59(1):176-184. doi:10.1167/ iovs.17-22002

41. Borderie M, Grieve K, Irsch K, et al. New parameters in assessment of human donor corneal stroma. Acta Ophthalmol. 2017;95(4):e297306. doi:10.1111/aos.13351

42. Sridhar M, Martin R. Anterior segment optical coherence tomography for evaluation of cornea and ocular surface. Indian J Ophthalmol. 2018;66:367-372. doi:10.4103/ijo.IJO_1005_17

43. Aristeidou A, Taniguchi EV, Tsatsos M, et al. The evolution of corneal and refractive surgery with the femtosecond laser. Eye Vis. 2015;2(1):12. doi:10.1186/s40662-015-0022-6

44. Shah SU, Gritz DC. Application of the femtosecond laser LASIK microkeratome in eye banking. Curr Opin Ophthalmol. 2012;23 (4):257-263. doi:10.1097/ICU.0b013e3283541c76

45. Group CDSI. The effect of donor age on corneal transplantation outcome. Results of the Cornea Donor Study. Ophthalmology. 2008;115(4):620.

46. Mannis MJ, Holland EJ, Gal RL, et al. The effect of donor age on penetrating keratoplasty for endothelial disease: graft survival after 10 years in the cornea donor study. Ophthalmology. 2013;120 (12):2419-2427. doi:10.1016/j.ophtha.2013.08.026

47. Puente MA, Patnaik JL, Lynch AM. et al. Association of federal regulations in the United States and Canada with potential corneal donation by men who have sex with men. JAMA Ophthalmol;2020. 1143-1149. doi:10.1001/jamaophthalmol.2020.3630

48. Biologics Guidances | FDA; 2021. Available from: https://www.fda. gov/vaccines-blood-biologics/guidance-compliance-regulatoryinformation-biologics/biologics-guidances. Accessed June 24, 2021.
49. Moshirfar M, Brown TW, Goldberg JL, Wagner WD, Ronquillo YC. Transgender corneal donors: a dilemma worthy of attention. Ophthalmol Ther. 2018;7:217-222. doi:10.1007/s40123-018-0148-4

50. O'Day DM. Diseases potentially transmitted through corneal transplantation. Ophthalmology. 1989;96(8):1133-1138. doi:10.1016/S0161-6420(89)32762-X

51. Matthews WB. Creutzfeldt-Jakob disease. Postgrad Med J. 1978;54 (635):591-594. doi:10.1136/pgmj.54.635.591

52. Borderie VM. Donor selection, retrieval and preparation of donor tissue: donor selection. Dev Ophthalmol. 2009;43:22-30.

53. Transmission of viruses through corneal transplantation - PubMed. Available from: https://pubmed.ncbi.nlm.nih.gov/16122153/. Accessed June 10, 2021.

54. Remeijer L, Maertzdorf J, Doornenbal P, Verjans GMGM, Osterhaus ADME. Herpes simplex virus 1 transmission through corneal transplantation. Lancet. 2001;357(9254):442. doi:10.1016/ S0140-6736(00)04011-3

55. Aldave AJ, Dematteo J, Glasser DB, et al. Report of the Eye Bank Association of America medical advisory board subcommittee on fungal infection after corneal transplantation. Cornea. 2013;32 (2):149-154. doi:10.1097/ICO.0b013e31825e83bf

56. Toro M, Choragiewicz T, Posarelli C, Figus M, Rejdak R. Early impact of covid-19 outbreak on the availability of cornea donors: warnings and recommendations. Clin Ophthalmol. 2020;14:2879-2882.

57. Nishioka SDA, Gyorkos TW. Tattoos as risk factors for transfusion-transmitted diseases. Int J Infect Dis. 2001;5(1):27-34. doi:10.1016/S1201-9712(01)90045-1

58. Desautels JD, Moshirfar M, Martheswaran T, Shmunes KM, Ronquillo YC. Risks posed to corneal transplant recipients by COVID-19-affected donors. Ophthalmol Ther. 2020;9:371-379. doi:10.1007/s40123-020-00254-w

59. Karimi S, Arabi A, Shahraki T, Safi S. Detection of severe acute respiratory syndrome Coronavirus- 2 in the tears of patients with Coronavirus disease 2019. Eye. 2020;34(7):1220-1223. doi:10.1038/s41433-020-0965-2

60. Arora R, Goel R, Kumar S, et al. Evaluation of SARS-CoV-2 in tears of patients with moderate to severe COVID-19. Ophthalmology. 2020;128(4):494-503. doi:10.1016/j.ophtha.2020.08.029

61. Cheong KX. Systematic review of ocular involvement of SARS-CoV-2 in coronavirus disease 2019. Curr Ophthalmol Rep. 2020;8:185-194. doi:10.1007/s40135-020-00257-7

62. Collin J, Queen R, Zerti D, et al. Co-expression of SARS-CoV-2 entry genes in the superficial adult human conjunctival, limbal and corneal epithelium suggests an additional route of entry via the ocular surface. Ocul Surf. 2021;19:190-200. doi:10.1016/j.jtos.2020.05.013

63. Sawant OB, Singh S, Wright RE, et al. Prevalence of SARS-CoV-2 in human post-mortem ocular tissues. Ocul Surf. 2021;19:322-329. doi:10.1016/j.jtos.2020.11.002

64. European Eye Bank Association. Ocular Tissue Donation: EEBA Donor Screening Guideline for SARS-CoV-2. https://www.eeba.eu/ news/news-details/ocular-tissue-donation-eeba-donor-screeningguideline-for-sars-cov-2

65. AlMutlak M, Li JY, Bin Helayel H, Fairaq R. Future of corneal donation and transplantation: insights from the COVID-19 pandemic. Cornea. 40(3):274-276. doi:10.1097/ICO.0000000000002538.

66. Ang M, Moriyama A, Colby K, et al. Corneal transplantation in the aftermath of the COVID-19 pandemic: an international perspective. Br J Ophthalmol. 2020;104:1477-1481.

67. Bartakova A, Kuzmenko O, Alvarez-Delfin K, Kunzevitzky NJ, Goldberg JL. A cell culture approach to optimized human corneal endothelial cell function. Investig Ophthalmol Vis Sci. 2018;59 (3):1617-1629. doi:10.1167/iovs.17-23637

68. COVID-19 Updates - Eye Bank Association of AmericaEye Bank Association of America; 2021. Available from: https://restoresight. org/covid-19-updates/. Accessed June 24, 2021. 


\section{Publish your work in this journal}

Clinical Ophthalmology is an international, peer-reviewed journal covering all subspecialties within ophthalmology. Key topics include: Optometry; Visual science; Pharmacology and drug therapy in eye diseases; Basic Sciences; Primary and Secondary eye care; Patient Safety and Quality of Care Improvements. This journal is indexed on PubMed
Central and CAS, and is the official journal of The Society of Clinical Ophthalmology (SCO). The manuscript management system is completely online and includes a very quick and fair peer-review system, which is all easy to use. Visit http://www.dovepress.com/ testimonials.php to read real quotes from published authors. 